\title{
The Eastern Borderland in Polish Collective Memory
}

\author{
M. Banaszkiewicz
}

For citation: Banaszkiewicz M. The Eastern Borderland in Polish Collective Memory. Vestnik of Saint Petersburg University. History, 2020, vol. 65, iss. 1, pp. 297-309.

https://doi.org/10.21638/11701/spbu02.2020.117

The eastern frontier of the Polish-Lithuanian Commonwealth is referred to in the Polish language as the Kresy. The geographical extent of this area changed with the shifting borders of the Polish-Lithuanian state and, after 1918, of Poland alone. At the time when modern Polish national consciousness was being shaped, it denoted the Russian territory known as the "western provinces" (gubernias)." Beginning with the mid-19 ${ }^{\text {th }}$ century, the Kresy were primarily a concept of the Polish political vocabulary that referred to an axiological space. The dispute over the area took the shape of a cultural and civilizational confrontation between two projects, those of imperial Russia and Poland. This article presents the Polish perception of the Kresy mostly as an imagined, not a real area. In the author's view, in order to explain it one has to employ categories of memory studies. The conflict over the Kresy took place when Polish national consciousness was being formed under the influence of Romanticism. This led to the permanent inclusion of Kresy mythology and to the conviction about the existential nature of the conflict with Russia in the Polish memory. The existence of the Kresy as a historical phenomenon ceased with the end of the Second World War. The area, however, continues to play an important role in memory and imagination. The author notes the most important threads of discussions on the Kresy heritage in public life. Attention is also paid to the renewed interest that the discourse on the Eastern Borderland has enjoyed in official Polish politics of memory in recent years.

Keywords: politics of memory, the Polish-Lithuanian Commonwealth, Kresy, collective memory, political mythology.

\section{Восточное пограничье в польской коллективной памяти}

\section{М. Банашкевич}

Для цитирования: Banaszkiewicz M. The Eastern Borderland in Polish Collective Memory // Вестник Санкт-Петербургского университета. История. 2020. Т.65. Вып. 1. С.297-309. https://doi.org/10.21638/11701/spbu02.2020.117

Mikolaj Banaszkiewicz - PhD, Associate Professor, Jagiellonian University, Gołębia 24, 31-007 Kraków, Poland; Visiting Researcher, St. Petersburg State University, 7-9, Universitetskaia nab., St. Petersburg, 199034, Russian Federation; mikolaj.banaszkiewicz@gmail.com

Миколай Банашкевич - PhD, доцент, Ягеллонский университет, Польша, 31-007, Краков, ул. Голембия, 24; приглашенный исследователь, Санкт-Петербургский государственный университет; Российская Федерация, 199034, Санкт-Петербург, Университетская наб., 7-9; mikolaj.banaszkiewicz@gmail.com

This research was supported by the grant No. 19-18-00073 "National Identity in the Imperial Politics of Memory: History of The Grand Duchy of Lithuania and the Polish-Lithuanian State in Historiography and Social Thought of the $19^{\text {th }}-20^{\text {th }}$ Centuries" of the Russian Science Foundation.

Исследование выполнено в рамках гранта № 19-18-00073 «Национальная идентичность в имперской политике памяти: история Великого княжества Литовского и Польско-Литовского государства в историографии и общественной мысли XIX-XX вв.» Российского научного фонда.

(c) Санкт-Петербургский государственный университет, 2020 
Восточное пограничье Речи Посполитой Обоих Народов получило в польском языке название Кресы. Географические пределы этой области менялись вместе с границами Польско-литовского государства, а после 1918 г. - Польши. В эпоху, ставшую ключевой для формирования нынешней польской национальной идентичности, под этим понятием подразумевалась территория западных губерний Российской империи. Начиная с середины XIX в. в польском политическом лексиконе Кресы были понятием, относившимся прежде всего не к физическому, а к аксиологическому пространству. Спор о характере этих земель приобрел вид культурного и цивилизационного противостояния двух проектов: имперского (русского) и польского. В статье описано польское восприятие Кресов как территории не столько реальной, сколько воображаемой. По мнению автора, понимание этого явления требует обращения к категории изучения памяти. Конфликт, связанный с Кресами, пришелся на тот период, когда польская идентичность формировалась под влиянием романтических идей. Это привело к укоренению в коллективной памяти поляков мифологии Кресов, а также к уверенности в экзистенциальном характере конфликта с Российской империей. История Кресов как исторического явления закончилась после Второй мировой войны. Однако Кресы продолжают жить в человеческих представлениях и памяти. Автор дает обзор основных тенденций в современных дискуссиях: о наследии Кресов в польской общественной жизни; о польском вкладе в историю литовских, белорусских и украинских земель, наконец, о месте России в политической рефлексии над будущим Центральной и Восточной Европы. Он обращает внимание также на рост значения Кресов в официальной польской политике памяти последних лет. Статья завершается наблюдением, суть которого в том, что появление на территории бывшего польско-российского пограничья новых государств и зрелых национальных идентичностей (литовской, украинской и белорусской) вскрывает конфликты памяти и представлений о прошлом этой территории и ее жителей.

Ключевые слова: политика памяти, Речь Посполитая Обоих Народов, Польша, Кресы, коллективная память, политическая мифология.

\section{Preliminary remarks}

Defining the focus of this article appears simple only on the surface. Despite the immediate association, the Polish Kresy is not a strictly defined territory, and therefore all attempts to delineate its borders inevitably run into difficulties. Making this effort, while necessary, will reveal the limited usefulness of historical geography ${ }^{1}$. On the other hand, the Kresy is not an abstract construct of political thought that can be analysed without a precise temporal and spatial location. Capturing this notion, straddled between physical reality and intellectual abstraction, is possible thanks to a research perspective offered by memory studies. This perspective allows to appreciate the importance of social imaginations in the historical process and to trace how such imaginations become the inseparable component of the imaginarium of political communities. Today, there is not the slightest doubt that the impact of social imaginations held by conscious members of large collectives is no less forceful than "real" events".

The memory studies perspective is sometimes opposed on methodological grounds by traditional academic historians. One of the objections put forward is that collective memory is difficult to study because of its volatile, changeable and easily distorted na-

${ }^{1}$ Cf.: Brown K. A Biography of No Place. From Ethnic Borderland to Soviet Heartland. Cambridge, MA, 2005. P. 2-3.

${ }^{2}$ Baczko B. Les imaginaires sociaux. Mémoires et espoirs collectifs. Paris, 1984. P. 14. 
ture $^{3}$. As regards the Kresy, acknowledging these inconveniences appears a necessity that researchers who attempt to present memory studies in academic terms must consider. As noted by the authors of the first Polish encyclopaedia of the Kresy (with 3,600 entries), an attempt to intellectually grasp this topic involves "entering a world which has in fact ceased to exist, a world whose most important manifestations are memory and imagination" . At the same time, the effort taken to familiarize the contemporary reader with this vanished world is motivated by the intention to reintroduce the lives, events, spiritual and material traces, and other phenomena that have been largely or entirely forgotten into the sphere of present-day memory. In other words, the cultural dimension of the Kresy idea has dominated Polish historical awareness to such a degree that it cannot be understood by standard methods of historical research.

The case offered by the Polish perception of the Kresy is interesting for at least three reasons. First, its conceptualization occurred when the modern notion of national identity was emerging owing to the influence of Romanticism. The importance of this remark is not just limited to stating a historical fact. On the contrary, one of the pivots of Polish post1989 intellectual debates is the dispute concerning the validity of the Romantic heritage in the post-political world. Romantic thinking dubbed by its opponents the source of all Polish ills and of self-destructive political idealism is seen by those who advocate it as an epitome of the vigorous national spirit and of the appeal of the Polish messianic idea. The latter was to be fulfilled in Poland's mission to civilize the east. Secondly, when the notion of the Kresy took a concrete shape, Poland did not exist as an independent political entity. As the term referred to territories swallowed by Russia, it was precisely the Russian state that became the focal point of Polish political thought. The future fate of the Kresy appeared to be inextricably bound with the Polish question: the search for solutions to that question was based on devising ways of dismantling or at least weakening the Russian Empire. The Polish ideas of regaining independence, notwithstanding their varied degrees of possibility of implementation in the European geopolitical reality, always looked back to the point of origin that is the pre-partition borders of 1772 . Thirdly, the Kresy issue was also promoted by those Polish elites whose fates were not dependent on Russia. To explain this phenomenon, one must refer to the mentality of those elites, whoadhered firmly to the ideology of Sarmatism. From their standpoint, the map of the Polish state confined by Russia into the ethnos-based boundary was entirely incompatible with the mental map of the Polish-Lithuanian Commonwealth in its heyday. The conviction about the Polish character of the Kresy, therefore, was not (and is not) a symptom of deficient political realism or, even less so, a manifestation of an obsessively anti-Russian sentiment. What it did reflect was the boundary of Polish cultural influences that formed part of Polish historical awareness.

\section{The Kresy geography}

The Polish literature on the subject is not unanimous with regard to the meanings of the term "Kresy" or its original usage ${ }^{5}$. However, resolving these doubts, which is a

\footnotetext{
${ }^{3}$ Kelley D. R. Frontiers of History. Historical Inquiry in the Twentieth Century. New Haven CT, 2006. P. 241-242.

${ }^{4}$ Encyklopedia Kresow / eds M. Karolczuk-Kedzierska et al. Krakow, [2004]. P.9.

${ }^{5}$ Cf.: Zurawski vel Grajewski P. Kresy - dzieje pewnego pojecia // Teologia Polityczna. 2015-2016. Iss. 8. P. 160-164.
} 
task that can only be tackled by means of in-depth research into the relevant literary and linguistic matters, is not of primary importance to us. Regardless of the etymology of the word, its contemporary usage is clear for Polish speakers. In Old Polish, it meant the line of border guard posts along the south-eastern frontier of the Rzeczpospolita. It was probably not widely used; the usual understanding is that it found a permanent place in the Polish language thanks to Wincenty Pol, a poet, geographer and participant in the November Uprising. It first appeared in the above meaning in Pol's Mohort poem published in 1854. Philological research (based, for instance, on studying the contents of dictionaries) has demonstrated with a considerable probability that at the turn of the $20^{\text {th }}$ century the word "kresy" was used fairly rarely.

As a geographical term, the word "Kresy" denoted some of the lands belonging to the Polish-Lithuanian Commonwealth that were absorbed into the Russian Empire in the second half of the $18^{\text {th }}$ century. Strictly speaking, these were the territories incorporated into Russia as its western provinces (gubernias) as opposed to the Kingdom of Poland that was established in 1815 in a personal union with the Russian Empire, from which it was separated by a customs and passport border. In Polish terminology, the former were referred to as the "taken lands" ("ziemie zabrane"). This designation carried the implicit suggestion of their eventual recovery, confirming that the shrunk borders of the Kingdom of Poland were only temporary and unacceptable in the long run. The dashed hopes of extending the Kingdom eastwards are considered one of the factors that led to the November Uprising ${ }^{6}$. As noted by Roman Wapinski, until the second half of the $19^{\text {th }}$ century Polish elites did not consider a turn of events in which the former south-eastern fringes of the Rzeczpospolita would be permanently lost to the sphere of Polish influence. The realization that such a scenario could materialize came with the January Uprising, in which the support offered to the insurgency by local communities of that region was minimal. The situation in Lithuania was entirely different as the Polish national sentiment was more pronounced in that area. In both cases, Polish political thinkers overestimated the appeal of the sense of belonging to the Polish nation defined as a historical (not ethnic) category. At the same time, they downplayed the potential for growth of Ukrainian, Lithuanian and Belarussian nationalisms ${ }^{7}$.

There are important reasons for arguing that the term "Kresy", when it first appeared in the Polish political vocabulary, was a concept referring not so much to a physical but rather to a cultural and axiological space. This peculiarity was noticed long ago by Jacek Kolbuszewski, who noted that when Pol's Mohort saw the light, the Kresy had long been severed from the Rzeczpospolita. In fact, the poet's praises were directed not at a region with specific geographical coordinates, but at the attitude taken by its defenders. The protagonist of this chivalric rhapsody is a semi-legendary personage who fought at Boruszkowce during the 1792 Polish-Russian War. The trail of interpretation devised by Pol was followed by other writers and poets who discussed related subjects. In the popular view, the Kresy came to signify a space where patriotic values could become manifest, whereas the term itself gained a pronounced and unambiguous moral connotation. Yet, since the

${ }^{6}$ Kieniewicz S. Kresy. Przemiany terminologiczne w perspektywie dziejowej // Przeglad Wschodni. 1991. Vol. 1, iss. 1. P. 4.

7 Wapinski R. Kresy w polskiej mysli politycznej w XIX i XX wieku (do roku 1945) // Kresy — pojecie i rzeczywistosc / ed. by K. Handke. Warszawa, 1997. P. 88-93. 
Kresy were not substituted for a geographical area, the latter was identified with the spirit of Polishness ${ }^{8}$.

The vicissitudes of the term illustrate well the supremacy of mythical geography over cartography that describes specific territories by using geographical symbols. As pointed out by Stanislaw Uliasz, in $19^{\text {th }}$-century Polish culture the Kresy became a space where national identity could be manifested. What brought this identity together was an attachment to the same symbols, which produced similar associations in all members of the community. This explains why the Polish population, despite often being a minority in the western provinces (gubernias), often asserted themselves as being in charge of these territories or at least as their lawful inhabitants. Of key importance here was not the congregation of individuals but the symbolic topography that was ingrained in cultural memory. One result of that factor was the emphasis laid on the notion of the manorial estate as the mainstay of Polishness that delineated the scope of its influence. (That emphasis was at times exaggerated, which led to skewed or entirely false perspectives on the actual balance of power ${ }^{9}$.)

Treating the Kresy as an axiological category par excellence is justified by the changing geographical extent of this area. During the struggles to establish the eastern border of reborn Poland, it was extended to Eastern Galicia. The territorial decisions stipulated by the Treaty of Riga (1921) cannot be underestimated. For one thing, it divided the disputed lands in a way that presaged future conflict. But what should be of more interest is the fact that the extent of the Kresy markedly shifted westwards. With this, the idée fixe of pre-independence Polish political thought, that is, restoring the Polish state to its pre-partition borders, was ultimately scrapped. This was tantamount to abandoning the lands located east of the demarcation line once and for all ${ }^{10}$. Obviously, all ideas of territorial expansion or of assimilating the local populations would have to be ranked as utopian. However, from a psychological point of view, this shift was of seminal importance. Even more importantly for the present discussion, the notion of the Kresy lost its connotation of the multinational, peripheral area of the Polish-Lithuanian Commonwealth; the areas that came to be regarded as the Kresy formed the central part of the imagined map of Poland. The Kresy became more susceptible to closer identification, both in symbolic and actual terms, with the nation state dominated by Poles. This process was precipitated by the looming threat of the Soviet Union ${ }^{11}$.

\section{The Kresy in Polish political imagination}

Literature was a factor that played a vitally important role in the political imagination of the successive generations of Poles. It was in literature that the Kresy idea found its most complete expression. One might even say that the belief about the cultural and political integration of Ukraine and the lands of the Grand Duchy of Lithuania with Poland was

${ }^{8}$ Kolbuszewski J.: 1) Kresy. Wroclaw, 1995. P. 18-23; 2) Kresy jako kategoria aksjologiczna // Kresy pojecie i rzeczywistosc / ed. by K. Handke. Warszawa, 1997. P. 120-122, 125, 127.

9 Uliasz S. Kresy jako przestrzen kulturowa // Ibid. P. 132-133.

10 Tomaszewski J. Kresy Wschodnie w polskiej mysli politycznej XIX i XX w. // Miedzy Polska etniczna a historyczna / ed. by W. Wrzesinski. Wroclaw, 1988. P. 116.

${ }^{11}$ Kiersnowski $R$. Kresy przez male i wielkie "K" - kryteria tozsamosci // Kresy - pojecie i rzeczywistosc. P. 110-112. 
to a large extent a result of the long-standing influence of poetry and prose. Descriptions of landscapes so different from those recognizable to the inhabitants of core Polish lands and of figures displaying heroic ideals helped to familiarize the Kresy and even to develop an emotional bond with those regions. Poetry and novels are a reflection of the political myths on the astonishing resistance to Russification policies employed by the Tsardom. Probably the two most important ones presented the Kresy as an Arcadian world, a retrospective utopia, and as the redoubt of Polishness, which in turn was another form of the Sarmatian myth of Poland as the bulwark of Christendom ${ }^{12}$.

Kresy themes had been present in Polish literature long before the historic struggle between the Rzeczpospolita and Russia with the latter emerging as winner. All the same, the heyday of the idealization the Kresy in the form of political mythology did not take place until Poland had lost its independence. This observation helps to understand the psychological reasons why the Polish view of the lost territories developed in this way. The social consciousness of the conquered nation was pervaded by victimization, which completely erased all potential for the sense of guilt on the part of the former stewards over the eastern lands towards the native populations of the Kresy. The collective memory formed in this process has survived all historical vicissitudes. The tragic experiences of the Second World War with its ethnic cleansings added to it an air of timelessness. Today, that memory is a major obstacle in adopting an approach of empathy to other ethnic communities in the Kresy, at times making such approaches impossible. There is a concern that alternative discourses will detract from the narrative that serves as the backbone of Polish political imagination. Defending the vision of that area as an axiological space is thus construed as defending historical memory against historical amnesia on the one hand and amputation of cultural awareness on the other ${ }^{13}$.

The rise in prominence in the public discourse that the Kresy have been successively experiencing (or the symbolic restitution of the meaning embedded in this term) has had a considerable impact for reflection in the humanities. This is truly a longue durée phenomenon. Its analysis requires using suitable research approaches.The discipline of memory studies, which is now blossoming in Poland (and also in Russia), seems to be particularly helpful. Studies on the Kresy as a place of memory allow critically and objectively assessing it both in terms of vitality and mythopoetic potential of the place. As intended by the proponent of the term "lieu de mémoire", this particular place of memory should be understood not only in its literal (i.e. topographic) but also figurative sense ${ }^{14}$.

Observations of contemporary Polish social life reveal a powerful longing for the Kresy. The nostalgia is the more intense because for several decades attempts had been made to erase this geographical area from the collective awareness. The social engineering methods applied to that end were only partially successful. Certainly, the state borders set in Yalta became established and inviolable. This was due to the opinion that its guarantor, the USSR, was all-powerful, and to the fear of Germany's revisionist policies. Their historical underpinning played an important role as well: Poland's post- 1945 borders carried

12 Hadaczek B. Kresy w literaturze polskiej. Studia i szkice. Gorzow Wielkopolski, 1999. P.9-40.

${ }^{13}$ Kasperski E. Dyskurs kresowy. Kryteria, wlasnosci, funkcje // Kresy - dekonstrukcja / eds K. Trybus, J.Kalazny, R. Okulicz-Kozarzyna. Poznan, 2007. P.97-101; Czaplejewicz E. Czym jest literatura kresowa // Kresy w literaturze. Tworcy dwudziestowieczni / eds E. Czaplejewicz, E. Kasperski. Warszawa, 1996. P. 12-18, 55-64.

${ }^{14}$ Nora P. General Introduction: Between Memory and History // Realms of Memory. Rethinking the French Past. Vol. 1: Conflicts and Divisions / ed. by L. D. Kritzman. New York, 1996. P. 16-19. 
associations with the geographical shape of the Polish state under the early Piasts. At the same time, the Kresy as an imagined area remain an inseparable component of Polish history and culture. Even more importantly, the Kresy are still one of the key categories of public discourse, irrespective of all regionalisms. A partial explanation of this is the continuous presence of this topic in Polish high and popular culture that dates back to the mid- $19^{\text {th }}$ century. To a greater extent, however, it is due to the scattering of those who carried the family memories of the Kresy all across Poland following the post-war migrations ${ }^{15}$.

The Poland's People Republic attempts to delete the Kresy as a subject of public awareness failed owing to, among other factors, the authority enjoyed by the anti-Communist emigrés. During the successive decades following the Second World War, their two most important centres were located in Paris and London. They were symptomatically at odds as far as their attitudes to the historical Polish lands are concerned. The London expatriate community persisted in demanding the restoration of the 1939 borders $^{16}$. This idea did not elicit much support from the elite: most of its members subscribed to a different concept that was promoted by Jerzy Giedroyc, the editor of the opinion-making "Kultura" periodical. It put forward abandoning the desire to recover the former Polish lands in the east at the expense of the neighbouring states. The reasons were geopolitical in character: Ukraine, Lithuania and Belarus were to serve as a buffer wedged between the future Poland and Russia ${ }^{17}$. The memory of Polish heritage in the Kresy cannot overshadow the realistic assessment of geopolitical situation, and priority must be given to security concerns - this was the strategy that underlay the eastern policies of the successive post1989 governments.

\section{“The Russian question" and its role in Polish reflections on the Kresy}

In Polish collective imagination that developed in the $19^{\text {th }}$ century, the Kresy appeared mostly as a ground for the struggle with Russia over the spheres of influence. This association, even though it misleadingly downplayed the role of wars against Ottoman Turkey, was not unfounded. In fact, the Kingdom of Poland challenged the Orthodox Russian world already in the $14^{\text {th }}$ century by incorporating Halych Russia as well as parts of Volhynia and Podolia. The decision to annex these lands may be regarded as an episode in the conflict between Latin and Greek Christendoms. Undoubtedly, those events marked the beginning of the mission that aimed to include those territories into the zone of Western influence, a mission that took concrete shape with the foundation of the Polish-Lithuanian union in 1385 - this is when the history of the Kresy as a geographical area of major geopolitical and cultural importance for the Poles began. The political union with Lithuania inevitably involved Poland into the struggle over Western Rus' between the Grand Duchy of Lithuania and Muscovy. According to one interpretation, a certain role in attracting the Orthodox and Lithuanian elites was played from the very outset of that process by the Polish civilization model grounded in republican and libertarian values

15 Traba R. The Kresy as a realm of memory: the long history of persistence // Herito. Heritage, culture and the present. 2012. Iss. 8. P.79, 82.

16 Habielski R. Niezłomni, nieprzejednani: Emigracyjne "Wiadomości" i ich krag 1940-1981. Warszawa, 1991. P. 215.

${ }^{17}$ Korek J. Paradoksy paryskiej Kultury. Styl i tradycje myslenia politycznego. Lublin, 2000. P. 404. 
that ran counter to Russia's tradition of autocracy ${ }^{18}$. It is worth noting that even today an important thread in the Polish discussion about the Kresy (even if it is not always explicitly stated) is the debate over the chances to implement a modern version of what is known as the Jagiellonian idea.

It can be clearly seen that the Polish view of the Kresy is a combination of collective memory (to some extent mythologised by subordinating the vision of those territories to the general ideas of values realized there) and of attempts at finding methods of settling political relations in the region according to 21st-century geopolitical realities. A mature ideological expression of the latter is the concept of Central and Eastern Europe as an area distinct from both Western Europe and Russia ${ }^{19}$. Recognition of the distinct and most importantly - durable character of such a vast and varied territory is based on the hope that the collective memory (or rather memories) of its inhabitants can serve as its effective guarantee. Attempts to realise this concept in political terms, however, reveal the limitations of imagined geography when confronted with reality consisting not only of aspirations but also of grievances nursed by the nations of Central and Eastern Europe. In the context of the international relations that develop in the area, evaluation of Polish presence in the Kresy is markedly important.

In the recent Polish debates in the humanities, there has been a strong, if not dominant current that runs against the tide of historical memory ${ }^{20}$. The view of Daniel Beauvois that social relations in the Kresy were far from idyllic, and that the liability for this primarily rests on the Polish elite of landowners, is ever more often met with approval. In this approach, the fate of the Kresy was decided by economic relations that favoured landowners at the expense of downtrodden peasantry ${ }^{21}$. Adherents of this belief challenge the credibility of memoirs displaying the biased viewpoint of Polish elites that highlighted their contribution to the cultural and economic development of the region while glossing over the price paid by the lowest strata of society. It is obvious that accepting this reasoning must logically lead to rejecting the foundations on which the supremacy of the landowners was based, that is, political ideology. There occurs a paradigmatic shift: the Polish missionary idea becomes an instrument of oppression. More precisely, it is actually used for colonial and imperial purposes despite the insistence that the Polish model (as opposed to the Russian) has no such inclinations. Another round of this dispute was occasioned by the publication of Jan Sowa's book "The King's Phantom Body. A Peripheral Struggle with Modern Form"22.

In spite of the dominant current in research that emphasises a unique character of the Kresy as a social and cultural phenomenon, the Polish humanities have also seen the ascendancy of a trend that questions the special character of this area. Methodologically, it

18 Nowak A. Kresy - historia bez końca // Dzieje Kresow / ed. by M. Karolczuk-Kedzierska. Krakow, 2006. P.9-11.

19 Stryjek T. Europa Środkowa (Środkowo-Wschodnia), czyli o pochwale różnorodności i komparatystyki // Kwartalnik Historyczny. 2013. Vol. 120, iss. 4. P. 761-790.

${ }^{20}$ Zajas K. Kresy skreslone, czyli o polskiej wielokulturowosci // Wieloglos. 2009. Iss. 5-6. P.110113; Lozowska K.R. Dziedzictwo kompleksow. Kulturowa kleska Kresow? // Studia Etnologiczne i Antropologiczne. 2012. Vol. 12. P.7-8, 11.

${ }^{21}$ Beauvois D. Trojkat ukraiński. Szlachta, carat i lud na Wolyniu, Podolu i Kijowszczyznie 1793-1914. Lublin, 2005.

${ }^{22}$ Sowa J. Fantomowe cialo krola. Peryferyjne zmagania z nowoczesna forma. Krakow, 2011. P.327$340,448-455,495-503$. 
draws inspiration from comparative civilizational studies. Essential to it is the conviction that looking for parallels between occurrences taking place at various times and places provides added value to our knowledge about the world and enables to describe the object of interest in more accurate terms. This approach refuses to treat the Kresy as something special and sees it as simply another frontier territory with features typical of other borderlands, i.e. not only Polish, but also foreign territories that do not form part of Polish historical experience. We see here an attempt at universalizing historical experience with a view to finding common points. This sort of analysis of Kresy reality has an explicit polemical streak that breaks with stereotypes and demythologises historical figures and events.

The best conceptualized example of this approach was offered by the historian Jan Kieniewicz. In his view, the inhabitants of the border strip between Poland, Lithuania and Russia were faced with the question of choosing the civilization to which they wished to belong, either Russian or European. The Kresy belonged to the latter for two reasons. First, it was an emanation of the Rzeczpospolita, a project aimed at building a civilization whose European character was derived not from specific patterns but from its wellspring, namely, Western Christendom. Points of departure for the evaluation of this project in terms of its longevity and originality should be sought in other projects of the Early Modern Period. Such a comparison, Kieniewicz believes, is favourable for Poland since its expansion and growth was not as ruthless as elsewhere (for instance, in the United States). Secondly, the real dimension of the Kresy as a European area was bolstered by envisioning it as such. The mythology based on this belief supported and strengthened the resistance against Russian expansion. Importantly, even though the Republic of Poland was the medium through which European values were filtered to the Kresy, the choice of the European option by individual national communities in the early $20^{\text {th }}$ century occurred in opposition to both Russia and Poland ${ }^{23}$.

The above review leaves no doubt that the Russian question appears the fundamental frame of reference in almost all Polish approaches to Kresy topics. This is entirely understandable, given that from the mid- $17^{\text {th }}$ century onwards Muscovy was Poland's chief rival and was soon to establish a strong foothold in those regions after the downfall of Poland, when it came to hold sway over those lands. The history of the Kresy is simultaneously the history of the western fringes of the Russian Empire ${ }^{24}$ as Russia loomed large in both real and imagined geography.

\section{The Kresy in the official politics of memory}

A visible confirmation of the statement that the Kresy issue has recently gained importance in the Polish public discourse is a new direction taken by the official politics of memory. During the first twenty-five years following the political transformation, initiatives commemorating Polish presence in Lithuania, Belarus and Ukraine were the preserve of non-governmental organizations, with the occasional support of local government authorities. An essential role was also played by niche periodicals (such as the

${ }^{23}$ Kieniewicz J. Kresy jako przestrzen europejska // Dziedzictwo kresow - nasze wspolne dziedzictwo? / ed. by J. Purchla. Krakow, 2006. P.21-22.

${ }^{24}$ Glebocki H. Kresy imperium: szkice i materialy do dziejow polityki Rosji wobec jej peryferii, XVIIIXXI wiek. Krakow, 2006. P.7-13. 
conservative and nation-centred "Arcana" periodical published in Krakow) that advocated the restoration of the Kresy into Polish historical awareness, as well as by low-budget initiatives that focused its publishing activity on memoirs. In this period, a great many of the commemorative initiatives were grassroots in character and could not count on considerable support from the state administration. The need for an institutional framework of intellectual reflection was not acknowledged either. This is evidenced by the short-lived Kresy Institute founded in Warsaw in 2006 and the failed initiative to establish the Polish Institute of the Historical and Cultural Heritage of the Kresy in 2008. The role of the latter, as intended by its originator, was to promote integration of the academic community with a view to achieving two objectives: broadening the knowledge about the history and culture of the former territories of the Polish state and safeguarding the historical truth from the falsehoods produced by the neighbouring countries that propagated versions of political and cultural history detracting from the good name of Poland ${ }^{25}$.

The fact that proves the marginalisation of the Kresy in the most convincing manner is the lack of a national museum dedicated solely to that area. The existing museums are the result of the efforts of individuals or associations. Two such institutions established on the initiative of the Lvov and Kresy Foundation stand out as particularly noteworthy: the Kresy Museum in Wegliniec (Lower Silesia), established in 2001 and consisting of two railway cars located in the city park, and its analogue in Kuklowka Radziejowicka (Mazovia), founded in 2008 and situated in the replica of a $19^{\text {th }}$-century manor characteristic of the Kresy ${ }^{26}$. One should also mention the Kresy Museum in Lubaczow that was transformed from a state-funded institution into a local government facility in $2004^{27}$. The Kresy Museum in Ostrow Mazowiecka in turn has been established on an entirely private initiative ${ }^{28}$. Another project worthy of mention is the (still incomplete) virtual museum of the Kresy organised under the patronage of the Marshal of the Podkarpackie Region ${ }^{29}$. Admittedly, the material and spiritual heritage of eastern Polish lands is present in the collections and exhibitions of the most important Polish museums, but it is given much less prominence than it deserves considering the role that those lands played in the unfolding of Polish history ${ }^{30}$.

Against this background, the project of setting up a Museum of Poland's Former Eastern Lands that has been advocated by the ruling Law and Justice party since 2017 appears to be a radical innovation. Strictly speaking, this idea was first formulated in 2008, when the party was in opposition. It must be stated that it does meet the expectations of museum experts ${ }^{31}$. As envisaged by the Ministry of Culture and National Heritage, the facility is to be opened by 2023 in the monumental Lubomirski Palace in the centre of Lublin. The museum's intended location is not a coincidence. It was in Lublin that Poland

${ }^{25}$ Chlipalski A. O Instytut Polskiego Dziedzictwa Historii i Kultury Kresow Wschodnich // Dziedzictwo i pamiec Kresow Wschodnich Rzeczypospolitej. Materialy I muzealnych spotkan z kresami / ed. by A. Stawarz. Warszawa, 2009. P. 274.

${ }^{26}$ URL: http://www.muzeumlwowa.pl/ (accessed: 25.10.2019).

27 URL: http://www.muzeumkresow.eu/muzeum (accessed: 25.10.2019).

28 URL: https://www.facebook.com/muzeumostrow/ (accessed: 25.10.2019).

29 URL: http://www.kresymuzeum.pl/index.php (accessed: 25.10.2019).

30 Sacha M.I. Los niewidoczny? Kresy i Kresowianie jako temat ekspozycji muzealnych po 1989 roku // Muzealnictwo. 2019. Vol.60. P. 194.

31 Blacharska W. Muzeum kresowe - czy i komu potrzebne? Spojrzenie muzealnika - organizatora wystaw kresowych // Dziedzictwo i pamiec Kresow Wschodnich Rzeczypospolitej. II muzealne spotkania z Kresami / ed. by T. Skoczek. Warszawa, 2017. P. 414. 
and the Grand Duchy of Lithuania entered into a real union in 1569 (formerly, the main candidate cities were Wroclaw, where a great number of Poles from the Kresy had been relocated, and Gdansk). The proposals outlined by the deputy minister of culture and national heritage Jaroslaw Sellin and by the director of the Lublin Museum who is in charge of setting up the new museum make it possible to draw two conclusions. First of all, the chronological frame of the permanent exhibition is to range from the earliest stages of Polish statehood under the Piast dynasty until the Second World War which is regarded as the final chapter in the history of the Kresy. Secondly, the Kresy are to be presented as a space where populations of various ethnic, cultural and religious identities flourished in peace. The final concept of the new museum, to be presented in late 2019 or early 2020, is to reflect the findings of historians, art historians, literary scholars and museum experts participating in the project. Given that this new cultural institution will be financed from the state budget, it is only to be expected that its ultimate form will be accommodated to the general assumptions listed above $e^{32}$.

The announcements made so far enable to conclude that the Museum of Poland's Former Eastern Lands is to present a coherent vision of the presence of Poles in the Kresy, emphasising its positive impact on the development of the territory and its native inhabitants. Publicists compare this initiative to two other flagship Polish museum projects: the Warsaw Uprising Museum and the Gdansk Second World War Museum opened in 2004 and 2017 respectively. These parallels are not unfounded; each of these museums encapsulates a vision of Poland's place in world history and feeds into the discussions of models of national identity and patriotism. The debates concerning the scope of those museums have revealed a fundamental dispute about the desired 21st-century Polish politics of memory. However, besides their role in provoking reflection on the experiences of the past as an aid to understanding oneself, both museums have had another function: their task was to transpose such experiences to the historical awareness of visitors from outside Central and Eastern Europe. The purpose was therefore to complete the mainstream narratives of the Second World War events with a narrative that has so far not found its due place in the West ${ }^{33}$. It can be assumed that the planned Museum of Poland's Former Eastern Lands will contribute to that strategy. In other words, it may supplement the limited knowledge of this part of Europe among Western audiences with a narrative on a heterogeneous society that thrived within a state that combined monarchic and republican values.

\section{Final remarks}

While the notion of Kresy emerged relatively recently (in the $19^{\text {th }}$ century), it is bound to remain an inseparable component of Polish identity owing to its axiological associations. This is not decided by ambitions of territorial gains (demands to revise Poland's borders are absent from Polish public discourse), but by cultural factors. One simply cannot conceive of the heritage of Polish art and culture without authors born in or associated

32 Powstanie Muzeum Kresow Wschodnich. URL: https://ekai.pl/powstanie-muzeum-kresowwschodnich/ (accessed: 25.10.2019); Powstaje Muzeum Ziem Wschodnich Dawnej Rzeczypospolitej — nowa instytucja kultury. URL: http://mkidn.gov.pl/pages/posts/powstaje-muzeum-ziem-wschodnichdawnej-rzeczypospolitej-ndash-nowa-instytucja-kultury-9631.php (accessed: 25.10.2019).

33 Cf.: Machcewicz P. Po co nam Muzeum II wojny swiatowej? // Muzeum II wojny swiatowej. Katalog wystawy glownej. Gdansk, 2016. P.7-8. 
with the Kresy. One also cannot convincingly describe and explain the political history of the Polish state or the continuity of political traditions without referring to the First Polish Republic and the inter-war period; in both cases, the Kresy played an important role. Paradoxically, therefore, the current interest in this geographical area (and especially the imagined space it represents) is a result of confining the territory of Poland into its ethnic boundary. The current experiences of its homogenous society is out of touch with the ten centuries of the historical experiences or of Polish collective memory, even if we take the date of regaining independence in 1918 as a turning point. Finally, Polish political imagination cannot do without references to the long-standing cultural and historical confrontations with Russia in the Kresy, a factor that had a profound impact on the awareness and mentality of the Poles. It is probable that "the memory wars" in Eastern Europe ${ }^{34}$ will revise, in more ways than one, the outdated image of the Kresy as an area of confrontation between Polish and Russian nationalistic projects. A clash of historical visions is inevitable due to the fragmented memory of political communities that aspire to act as stewards of these lands.

\section{References}

Baczko B. Les imaginaires sociaux. Mémoires et espoirs collectifs. Paris, Payot Publ., 1984, 242 p.

Beauvois D. Trojkat ukraiński. Szlachta, carat i lud na Wolyniu, Podolu i Kijowszczyznie 1793-1914. Lublin, Wydawnictwo Uniwersytetu Marii Curie-Sklodowskiej Publ., 2005, 816 p.

Blacharska W. Muzeum kresowe - czy i komu potrzebne? Spojrzenie muzealnika - organizatora wystaw kresowych. Dziedzictwo i pamiec Kresow Wschodnich Rzeczypospolitej. II muzealne spotkania z Kresami. Ed. by T. Skoczek. Warszawa, Muzeum Niepodleglosci Publ., 2017, pp.411-414.

Brown K. A Biography of No Place. From Ethnic Borderland to Soviet Heartland. Cambridge, MA, Harvard University Press, 2005, 322 p.

Chlipalski A. O Instytut Polskiego Dziedzictwa Historii i Kultury Kresow Wschodnich. Materialy I muzealnych spotkan $z$ Kresami. Ed. by A. Stawarz, Warszawa, Muzeum Niepodleglosci Publ., 2009, pp. $273-$ 280.

Czaplejewicz E. Czym jest literatura kresowa. Kresy w literaturze. Tworcy dwudziestowieczni. Eds E. Czaplejewicz, E. Kasperski. Warszawa, Wydawnictwo „Wiedza Powszechna” Publ., 1996, pp. 7-73.

Glebocki H. Kresy imperium: szkice i materialy do dziejow polityki Rosji wobec jej peryferii, XVIII-XXI wiek. Krakow, Wydawnictwo Arcana Publ., 2006, 568 p.

Habielski R. Niezlomni i nieprzejednani. Emigracyjne "Wiadomosci" I ich krag 1940-1981. Warszawa, Panstwowy Instytut Wydawniczy Publ., 1991, 244 p.

Hadaczek B. Kresy w literaturze polskiej. Studia i szkice. Gorzow Wielkopolski, [s. n.], 1999, 300 p.

Kasperski E. Dyskurs kresowy. Kryteria, wlasnosci, funkcje. Kresy - dekonstrukcja. Eds K. Trybus, J. Kalazny, R. Okulicz-Kozaryn. Poznan, Wydawnictwo Poznanskiego Towarzystwa Przyjaciol Nauk Publ., 2007, pp. 89-103.

Kelley D. R. Frontiers of History. Historical Inquiry in the Twentieth Century. New Haven CT, Yale University Press, 2006, $320 \mathrm{p}$.

Kieniewicz J. Kresy jako przestrzen europejska. Dziedzictwo kresow - nasze wspolne dziedzictwo? Ed. by J. Purchla. Krakow, Miedzynarodowe Centrum Kultury Publ., 2006, pp. 13-24.

Kieniewicz S. Kresy. Przemiany terminologiczne w perspektywie dziejowej. Przeglad Wschodni, 1991, vol.1, iss. 1, pp. 3-13.

Kiersnowski R. Kresy przez male i wielkie "K" — kryteria tozsamosci. Kresy — pojecie i rzeczywistosc Kresy - pojecie i rzeczywistosc. Ed. by K. Handke. Warszawa, Slawistyczny Osrodek Wydawniczy Publ., 1997, pp. 109-118.

Kolbuszewski J. Kresy. Wroclaw, Wydawnictwo Dolnoslaskie Publ., 1995, 258 p.

${ }^{34}$ Koposov N. Memory Laws, Memory Wars. The Politics of the Past in Europe and Russia. Cambridge, 2018. P. 129-148. 
Kolbuszewski J. Kresy jako kategoria aksjologiczna. Kresy - pojecie i rzeczywistosc. Ed. by K. Handke. Warszawa, Slawistyczny Osrodek Wydawniczy Publ., 1997, pp. 119-129.

Koposov N. Memory Laws, Memory Wars. The Politics of the Past in Europe and Russia. Cambridge, Cambridge University Press, 2018, $338 \mathrm{p}$.

Korek J. Paradoksy paryskiej "Kultury". Styl i tradycje myslenia politycznego. Lublin, Wydawnictwo Uniwersytetu Marii Curie-Sklodowskiej Publ., 2000, 534 p.

Lozowska K. R. Dziedzictwo kompleksow. Kulturowa kleska Kresow? Studia Etnologiczne i Antropologiczne, 2012, vol.12, pp. 81-93.

Machcewicz P. Po co nam Muzeum II wojny swiatowej? Muzeum II wojny swiatowej. Katalog wystawy glownej. Gdansk, Muzeum II wojny swiatowej, 2016, pp.7-11.

Nora P. General Introduction: Between Memory and History. Realms of Memory. Rethinking the French Past. Vol. 1: Conflicts and Divisions. Ed. by L.D. Kritzman. New York, Columbia University Press, 1996, pp. 4-20.

Nowak A. Kresy — historia bez końca. Dzieje Kresow. Ed. by M. Karolczuk-Kedzierska. Krakow, Wydawnictwo Kluszczynski Publ., 2006, pp.7-12.

Sacha M.I. Los niewidoczny? Kresy i Kresowianie jako temat ekspozycji muzealnych po 1989 roku. Muzealnictwo, 2019, vol.60, pp. 193-207.

Sowa J. Fantomowe cialo krola. Peryferyjne zmagania z nowoczesna forma. Krakow, Towarzystwo Autorow i Wydawcow Prac Naukowych Universitas Publ., 2011, 584 p.

Stryjek T. Europa Srodkowa (Srodkowo-Wschodnia), czyli o pochwale roznorodnosci i komparatystyki. Kwartalnik Historyczny, 2013, vol. 120, iss. 4, pp. 761-790.

Tomaszewski J. Kresy Wschodnie w polskiej mysli politycznej XIX i XX w. Miedzy Polska etniczna a historyczna. Ed. by W. Wrzesinski. Wroclaw, Zaklad Narodowy im. Ossolinskich - Wydawnictwo Publ., pp. 97-118.

Traba R. The Kresy as a realm of memory: the long history of persistence. Herito. Heritage, culture and the present, 2012, iss. 8, pp. 58-91.

Uliasz S. Kresy jako przestrzen kulturowa. Kresy - pojecie i rzeczywistosc. Ed. by K. Handke. Warszawa, 1997, pp. 131-143.

Wapinski R. Kresy w polskiej mysli politycznej w XIX I XX wieku (do roku 1945). Kresy - pojecie $i$ rzeczywistosc. Ed. by K. Handke. Warszawa, Slawistyczny Osrodek Wydawniczy Publ., 1997, pp. 85107.

Zajas K. Kresy skreslone, czyli o polskiej wielokulturowosci. Wieloglos, 2009, iss. 5-6, pp. 110-121.

Zurawski vel Grajewski P. Kresy — dzieje pewnego pojecia. Teologia Polityczna, 2015-2016, iss. 8, pp. 159179.

Статья поступила в редакцию 12 июля 2019 г.

Рекомендована в печать 2 декабря 2019 г.

Received: July 12, 2019

Accepted: December 2, 2019 